\title{
The Role of Inspiration in the Helping Professions
}

\author{
Kari A. O'Grady \\ Loyola University \\ P. Scott Richards \\ Brigham Young University - Provo, scott_richards@byu.edu
}

Follow this and additional works at: https://scholarsarchive.byu.edu/facpub

Part of the Student Counseling and Personnel Services Commons

\section{Original Publication Citation}

O'Grady, K. A., \& Richards, P. S. (2010). The role of inspiration in the helping professions.

Psychology of Religion and Spirituality, 2, 57-66.

\section{BYU ScholarsArchive Citation}

O'Grady, Kari A. and Richards, P. Scott, "The Role of Inspiration in the Helping Professions" (2010). Faculty Publications. 3847.

https://scholarsarchive.byu.edu/facpub/3847

This Peer-Reviewed Article is brought to you for free and open access by BYU ScholarsArchive. It has been accepted for inclusion in Faculty Publications by an authorized administrator of BYU ScholarsArchive. For more information, please contact ellen_amatangelo@byu.edu. 


\title{
The Role of Inspiration in the Helping Professions
}

\author{
Kari A. O’Grady \\ Loyola University
}

\author{
P. Scott Richards \\ Brigham Young University
}

\begin{abstract}
This qualitative research study examined the ways that helping professionals experience inspiration, as defined as divine guidance or influence, in their therapeutic work. It also explored their beliefs about how helping professionals can seek inspiration in their work. Open-ended survey questions from 333 respondents from a diverse range of religious and professional backgrounds were qualitatively analyzed. The themes extracted give insight into the ways that these helping professionals have experienced inspiration in their work and about how helping professionals can facilitate a spiritual space in the therapeutic context.
\end{abstract}

Keywords: spirituality, psychotherapy, inspiration, helping professionals, theistic

Modern-day psychology and psychiatry developed during the late 19th and early 20th centuries (Karier, 1986). The mechanistic view of the physical universe dominated the scientific world at that time (Barbour, 1990; Burrt, 2003). Many scientists "believed that humanity was ... a part of the all-encompassing world machine, whose operation could be explained without reference to God. Such a materialistic world held no place for consciousness or inwardness except as subjective illusions" (Barbour, 1990, p. 220). Sigmund Freud and other early leaders in the behavioral sciences assumed that human behavior could be explained naturalistically; that is, without resorting to transcendent explanations. They also adopted deterministic, materialistic, and mechanistic views of human beings (Burrt, 2003; Karier, 1986; Leahey, 1991).

The naturalistic assumptions accepted by early behavioral scientists had an enduring impact on the mental health professions; however, the influence of this belief system has weakened during the past several decades. One important reason for this is that Albert Einstein's theory of relativity, Max Planck's quantum theory, and other scientific discoveries and viewpoints directly challenged the mechanistic and material-

Kari A. O’Grady, Pastoral Counseling Department, Loyola University Maryland; P. Scott Richards, Department of Counseling Psychology, Brigham Young University.

Correspondence concerning this article should be addressed to Kari A. O'Grady, Pastoral Counseling Department, 8890 McGaw Road, Columbia, MD 21045. E-mail: kaogrady@loyola.edu istic view of the universe (Barbour, 1990). The rise of modern-day physics also undermined positivistic views of epistemology and scientific knowledge by providing evidence that scientific theories and observations are only "partial representations of limited aspects of the world as it interacts with us" (Barbour, 1990, p. 99). Observing a phenomenon may alter the nature and properties of it, and human beings' ability to observe reality accurately may be fundamentally limited (Barbour, 1990; Mason, 1962). Many scholars now endorse epistemological and methodological pluralism, arguing that rational and intuitive ways of knowing have validity and that much can be learned from more subjective qualitative methodologies (e.g., Csikszentmihalyi, 1996; Denzin \& Lincoln, 1994; Simonton, 2004; Slife \& Gant, 1999; Richards \& Bergin, 2005).

Modern-day physics also helped open the door to the reconsideration of spiritual realities by scientists and helping professionals. A number of scientists have pointed out that current views of the universe are more compatible with some spiritual views of reality (e.g., Barbour, 1990; Capra, 1983; Davies, 1992; Peacocke, 2001; Polkinghorne, 1998). This realization has promoted increased dialogue between scientists and theologians (e.g., Davies, 1992; Griffin, 2000; Peacocke, 2001). In the medical and mental health professions, it has also helped stimulate interest in the role of faith and spirituality in treatment and healing (Koenig, McCullough, \& Larson, 2001; Plante \& Sherman, 2001; Richards \& Bergin, 2005). 
The growing interest during the past two decades in the role of spirituality in healing has led to the development of numerous spiritually oriented treatment approaches in the mental health professions (e.g., Richards \& Bergin, 2005; Sperry \& Shafranske, 2005). Some of these approaches are grounded in the thought of the Western theistic spiritual traditions, others in Eastern spiritual traditions, and yet others in specific psychological or multicultural theories (Richards \& Bergin, 2005; Sperry \& Shafranske, 2005). Virtually all of these approaches encourage helping professionals to address clients' spiritual concerns, if clinically indicated, and to use language and spiritual interventions that show respect for the healing potential of their clients' faith traditions.

We have devoted much of our efforts during the past decade to the development, application, and evaluation of a theistic spiritual framework for psychological treatment (e.g., O'Grady \& Richards, 2009; Richards \& Bergin, 2005). The assumptions of a theistic spiritual framework extend beyond materialistic and mechanistic assumptions to include the view that "God exists, that human beings are the creations of God, and that there are unseen spiritual processes by which the link between God and humanity is maintained" (Bergin, 1980, p. 99). We also assume that clients who have faith in God's power and draw on spiritual resources during treatment will have added strength to cope and heal.

One distinctive contribution a theistic perspective makes to the understanding of helping professionals' role is that they may seek spiritual guidance as they assess and intervene with their patients and clients. Research to date suggests that many helping professionals engage in personal prayer and other spiritual practices such as meditation (e.g., Richards \& Potts, 1995; Shafranske, 2000). Several qualitative studies with small samples of Latter-Day Saint, Quaker, and transpersonal psychotherapists have provided preliminary evidence that some helping professionals believe that they have experienced inspiration in their work (e.g., Chamberlain, Richards, \& Scharman, 1996; West, 2000; White, 2002). For example, some psychotherapists have reported experiencing a deep spiritual connection with their clients (Chamberlain et al., 1996; West, 2000; White, 2002). Some also have reported receiving inspiration that helped them more clearly assess and under- stand their clients' problems and implement effective therapy interventions (Chamberlain et al., 1996; West, 2000; White, 2002).

Although these qualitative studies have provided some rich insight into the inspiration experiences of some helping professionals, they were limited by the small sample sizes and restricted religious and professional diversity of the participants. We are not aware of any larger scale studies that have investigated the role of inspiration in therapeutic practice. We were interested in investigating whether helping professionals from a larger diversity of spiritual traditions and professional backgrounds believe that they have experienced inspiration in their work and what these experiences were like. We were also interested in gaining more insight into how helping professionals might go about seeking or preparing to receive inspiration in their work. Thus, the specific aims of this study were to investigate the following questions:

1. In what ways, if any, do helping professionals experience inspiration in their work?

2. How do helping professionals go about seeking or preparing to receive inspiration in their work?

\section{Method}

This study was conducted qualitatively in that we asked a diverse range of helping professionals to respond in writing to several openended questions concerning their views about inspiration in therapeutic practice. We qualitatively analyzed the written survey responses to discover themes in the responses. Multiple coders were used to help analyze the responses and ensure the trustworthiness of the findings.

\section{Description of the Survey}

The first page of the survey was a cover letter that explained the purpose of the survey, defined inspiration, and encouraged participation in the survey. The cover letter was followed by two closed-ended questions with "Yes," "No," and "Uncertain" response options: "Do you believe that God may inspire helping professionals as they work with their clients?" and "Have you ever personally felt God's inspiration in 
your professional practice?" These were followed by two open-ended questions: "Could you please describe an occasion when you have experienced inspiration in your professional practice?" and "What, if anything, do you believe helping professionals can do to qualify for and receive inspiration?"1 The final page of the survey contained questions about the demographic characteristics of the respondents. Participants were given a choice of completing a paper copy of the survey or an online version of it.

\section{Survey Respondents}

We collected data during 2004-2005 from two different populations to learn about the views of helping professionals from a variety of professional disciplines and from a diversity of theistic religious traditions. Sample 1 consisted of 85 members of Division 36 of the American Psychological Association who were randomly selected from the division's membership roster. Sample 2 consisted of 248 male and female helping professionals and scientists randomly selected from the mailing list of a monthly periodical with a national readership devoted to the interface of science and religion.

Not all respondents completed all of the questions in the demographic portion of the survey, but of those who did, there were 112 women and 149 men. The average age of the respondents was 54.8 years. Concerning the respondents' highest educational degree, 176 had a $\mathrm{PhD}, 13$ an MD, 12 an EdD, 3 a PsyD, 41 an MA, 27 an MS, 30 a master's in divinity or theology, and four licensed clinical social workers (LCSWs). The helping professionals had received their degrees in a wide variety of professional fields, including clinical psychology, counseling psychology, education, medicine, ministry, nursing, religious studies, social work, sociology, special education, and theology. The respondents were professionally accomplished as a group, having received a large number and variety of professional awards.

Of the respondents, 217 indicated they were theistic, 20 indicated they were agnostic, eight indicated they were atheistic, and the remaining respondents left this question blank. In regards to religious affiliation, there was considerable diversity among the respondents, including 44 Roman Catholics, 14 Baptists, 18 Presbyteri- ans, 16 Methodists, 11 Episcopalians, six Lutherans, six Quakers, six Unitarians, six Evangelicals, five Jews, and four United Church members. There were also a number of respondents who did not specify a particular denomination, but referred to themselves as Christians $(n=22)$ or Protestant $(n=11)$. There was also a wide variety of other religious affiliations represented in the sample in small numbers $(n<3)$, including Disciples of Christ, SeventhDay Adventists, Latter-Day Saints, Eastern Orthodox, Christian Scientists, Jehovah's Witnesses, Hindus, Taoists, Muslims, Buddhists, and Pantheists. Twenty-two respondents indicated they had no religious affiliation, nine characterized themselves simply as nondenominational, and the remaining respondents left this item blank.

\section{Data Analysis}

Survey responses were converted to an electronic format to allow for ease of memo writing, exchange of data between participating researchers, and manipulation of text. A research team was formed consisting of four undergraduate students, a professor of counseling psychology, and the principal investigator, who was an advanced doctoral student in counseling psychology. The research team was located at Brigham Young University, a privately owned university by the Church of Jesus Christ of Latter-Day Saints (LDS) with a population of nearly 30,000 students from over 120 countries throughout the world. The LDS church is a theistic religion that adheres to the belief that God exists and has an active influence in the world.

The research team divided up transcripts and found initial themes. Then the research team met to discuss, confirm, and reconsider themes. A devil's advocate was assigned to emphasize disconfirming responses and to challenge preconceptions that could influence the analysis of the data and the conclusions formulated. The assigned devil's advocate helped the research team avoid "groupthink" and consider fresh ways of viewing the data. The research team

\footnotetext{
${ }^{1}$ There were also four similar questions about the role of inspiration in science that were directed at the scientists in the two samples. The findings associated with these questions are reported in a separate paper.
} 
continued to collapse, relabel, and split categories until the data were saturated (no longer contributing further insight). After identifying and collapsing themes, the text was broken down into its smallest components of meaningful and independent thought, and each segment was assigned a theme or category (Erlandson, Harris, Skipper, \& Allen, 1993).

Following this stage of coding, the principal investigator reviewed all of the responses in light of the research questions and collapsed and relabeled themes. The principal investigator then looked at each theme again to select themes that could serve as representative quotes for the results section of the study. She then went back to these selected responses and viewed them in light of the respondent. She refined her selection to include the quotes that best represented the theme being discussed and the overall study. Explicit searches for disconfirming or contradictory cases in the survey responses were also conducted. These cases were carefully considered throughout the analysis and reporting stages of the study.

\section{Results}

Not all participants responded to the closedended questions, but of those who did, on the first closed-ended question, 284 respondents $(86.6 \%)$ indicated they that believe that God may inspire helping professionals as they work with their clients, $16(4.9 \%)$ indicated that they are uncertain about this, and 19 (5.8\%) indicated that they do not believe that God inspires helping professionals. On the second closedended question, 245 respondents $(74.7 \%)$ indicated that they have personally felt God's inspiration in their professional practice, $31(9.5 \%)$ indicated that they are uncertain about this, and $39(11.9 \%)$ said that they have not experienced God's inspiration in their professional practice.

\section{Themes for Open-Ended Question 1}

The first open-ended question was, "Could you please describe an occasion when you have experienced God's inspiration in your professional practice?" Table 1 summarizes the themes and subthemes that emerged in the analysis of the helping professionals' responses to open-ended Question 1.
Table 1

Themes for Helping Professionals' Responses to

Open-Ended Question 1: Could You Please

Describe an Occasion When You Have Experienced God's Inspiration in Your Professional Practice?

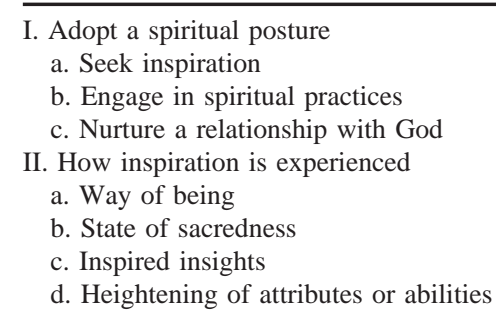

Adopt a spiritual posture. There was substantial overlap in the participants' responses to the two open-ended questions. Many participants referred to their own spiritual processes and practices rather than, or in addition to, experiences of God's inspiration in their work. For many, sharing the processes of developing a spiritual posture was the most important response to the first open-ended question.

Seek inspiration. Helping professionals in our study stated that they were more likely to experience inspiration in their work with clients and patients when they prayed or sought God's inspiration. They also indicated that they were more inclined to have spiritual, intuitive experiences in their work with others when they pray with and for the other. For instance a psychologist shared,

\begin{abstract}
There have been many times when I feel personally unable to dig beneath the intellectual defenses a client presents. At these times I often find myself in a posture of prayer, looking for divine direction. I often find a sense of God leading me to places of paradox that result in moving deeper in the therapeutic explorations. This is hard to put into words because the work of God is often mysterious and all our training in psychology moves the other direction-toward description and analysis.
\end{abstract}

Engage in spiritual practices. Respondents also noted that they experienced an increased awareness of God's inspiration in their work when they participated in spiritual practices, especially when they engaged in the practice of meditating or reading sacred texts. For instance, a clinical psychologist stated, "I have often had the experience that a verse of scripture read during morning devotionals was directly helpful or applicable in working with a patient that 
day." Some also said that they experienced God's influence when they encouraged their clients and patients to engage in these practices.

Develop a relationship with God. A number of respondents stated that they experienced God's inspiration through developing a relationship with Deity. Participants listed a number of elements they deemed necessary for a healthy relationship with their Higher Power, including believing in God's existence, having faith and trust in God, loving God, and being willing to serve as an "instrument in God's hand." For instance, a medical doctor shared,

This occurs quite often as I ascend the steps to my office, I offer a prayer that I might be an instrument of God's grace and healing. He lifts me through the day, especially in serving the anxious, the depressed and the distressed patients. God's inspiration gives me patience with difficult patients who have been rejected by some of my doctor colleagues.

An LSCW said, "I find that if I am settled and balanced spiritually, and if my connection with God is strong, my work is effortless and I am truly "with' the person who has come to me for assistance."

How inspiration is experienced. Helping professionals in our study also stated that they experienced transcendent states in their work with their clients and patients. They shared experiences in which they felt the best explanation for the growth and healing that occurred for their clients and patients was "God in the midst." As described by a clinical psychologist, "In these moments, I feel that there is "something' larger and more 'powerful' than either the client and myself, which is "present."'

Within this theme, we observed four subthemes in the specific ways that the helping professionals described the ways they experienced inspiration during their therapeutic work.

Way of being. Some participants indicated that they experienced God's inspiration often or constantly. Some stated that God's inspiration was not a singular or outstanding experience, but rather a way of being, as offered by one counseling psychologist, "If I listen to the voice of my soul, which is the Spirit of God within me, I am a much better counselor." Likewise, a pastoral counselor responded, "If God is with you and in you, how can one occasion be different from another?"

State of sacredness. A few participants described feeling a sacred presence during a coun- seling session or medical visit or through the encounter, as related by an LCSW,

I feel there is a mystical quality to the therapeutic process. In that I am referring to a third force. There's the client, the therapist, and something else present. It's almost palpable when, what appears to be all of sudden, the client "gets it"- the "aha" experience. It is important to pay attention to all the subtleties present.

A chaplain stated, "I have felt God in the midst of interrelating with patients. A sense of blessedness becomes apparent, and I believe the patient notices this as well. This has been expressed by both myself and my clients as gratitude for the encounter."

Inspired insights. A number of participants shared experiences that they believe evidenced mystical influences in their work. Helping professionals in our study indicated that they experienced God's inspiration helping them arrive at a sudden insight, giving them the words to say to someone, leading them to the right person, guiding them toward an original approach, or helping them to perceive the needs of their patient or client. Some participants also stated that they believed God's inspiration was witnessed through sudden breakthroughs, serendipitous experiences, client and patient healing, and patients or clients affirming that the helping professional "hit the mark." For instance, a medical doctor shared,

\begin{abstract}
I have had a patient before me and as I set out to determine treatment I find inspiration for which treatment to use. The treatment is quite unusual for me to use in this particular case, and I have no idea why I would even think of doing it. But when I suggest it, and it is followed, the patient responds in the best possible manner of healing. If "I" would never have thought of using such a treatment plan, then I must have had divine inspiration.
\end{abstract}

Likewise, another helping professional reported,

\begin{abstract}
In my professional practice as a psychologist, I experience God being present in psychotherapy sessions with patients. I see my work as a prayerful experience always being trusting to the reality that God works through me if I am open to the experience. I believe my office is a sacred space, and that which transpires there is sacred and holy. With one particular patient who had a long history of major depressive disorder, I remember saying on one occasion to her "Do you pray?" She later told me that my asking that question was the turning point for her-the experience that set her on the path toward psychological and spiritual healing.
\end{abstract}

Heightening of attributes or abilities. Other helping professionals in our study described an 
increase in attributes of helping, such as improved ability to love, comfort, and understand their patients and clients. As stated by one respondent, "I do counseling and mentoring and have often 'felt' what I would call a 'divine enablement' in perceiving the person's concerns." Another respondent shared,

\begin{abstract}
My specialty is psychiatric nursing. I have had the opportunity to interact with patients who display active agitation and aggression. Through my verbal deescalation, I have been able to calm them and reassure them. At the time I was talking with them, I felt that a higher power was guiding me and providing information to use what would somehow get through the "static" noise of undirected speech. I have often felt that intuitive responses from me have startled a patient into a listening attitude that I could then use to present safe options to them. Many times the information I used startled me too.
\end{abstract}

\section{Themes for Open-Ended Question 2}

The second open-ended question asked, "What, if anything, do you think helping professionals can do to qualify for and receive inspiration from God?" Table 2 summarizes the themes and subthemes that emerged in the analysis of the helping professionals' responses to open-ended Question 2.

Other thoughts about inspiration. In response to the second open-ended question, a number of helping professionals offered their own views about the nature of inspiration. Two subthemes emerged in the analysis of these responses.

Inspiration is a gift. The most prevalent response to Question 2 was criticism of the terminology of the question. Many participants expressed their view that people do not qualify to receive inspiration. They preferred the per-

\section{Table 2}

Themes for Helping Professionals' Responses to Open-Ended Question 2: What, if Anything, Do You Think Helping Professionals Can Do to Qualify for and Receive Inspiration From God?

\footnotetext{
I. Other thoughts about inspiration

a. Inspiration is a gift

b. Denial of God as source of inspiration

II. Suggestions for receiving inspiration

a. Be open to inspiration

b. Actively seek inspiration

c. Nurture relationship with god

d. Live a virtuous life

e. Be present in relationship with clients
}

spective that inspiration is a gift from God-or grace-or that it is something people can be aware of or open to receive. For instance, one psychologist responded, 'I don't think there is any such thing as 'qualifying for' inspiration from God. It merely requires openness." A participant with a master's in social work asserted, "The only qualification for God's inspiration is a willingness to accept it."

Denial of God's inspiration. A few participants responded by asserting their disbelief in divine inspiration or by explaining their experiences in naturalistic terms. Others stated that they have never experienced God's inspiration in their work. For instance, one respondent said, "I believe that God is a myth." Another respondent with a PhD in psychology stated, "I don't know what God is. I think there are things that anyone can do to cultivate inspiration but I don't attribute such inspiration to God."

Suggestions for receiving inspiration. Respondents had a number of recommendations for helping professionals invite and be open to God's influence in their work. Five subthemes emerged in the analysis of these responses.

Be open to inspiration. Many helping professionals in our study recommended that other helping professionals transcend the tendency to consider only naturalistic explanations and resources and be open to the possibility of spiritual avenues in working with clients and patients. For instance, a respondent with a $\mathrm{PhD}$ in psychology suggested, "They need to have a prayer and faith in themselves to see beyond the limits of science and the material world." Other participants encouraged helping professionals to develop spiritual sensitivity through creativity, open-mindedness, and being still and listening to inner, intuitive dimensions of self. They suggested that this requires openness to an alternative framework for healing-one that includes God's guidance. For instance, one psychologist stated, "I believe the inspiration is always available. What we need to do is tune in by being in a place of compassion and love, listen for it, and then step aside." An LCSW responded, "Be still and listen. Embracing silence is key. Be imaginative. Don't be afraid. It is within imagination that we become god-like, in that we create (cocreate) something entirely new. Be an artist." A participant with a $\mathrm{PhD}$ in marriage and family therapy suggested, "Be aware of the possibility of 'divine' influence 
and inspiration in both the personal and interpersonal dimensions of life in all its complexities." Likewise, a respondent with a $\mathrm{PhD}$ in nursing suggested that helping professionals "reflect, listen to patients and [their] inner voice."

Actively seek inspiration. A number of respondents in our study suggested that helping professionals need to actively seek God's inspiration. A participant with a $\mathrm{PhD}$ in nursing recommended that helping professionals do the following:

Invite God in and $\mathrm{He}$ will come. No invitation and $\mathrm{He}$ will not come. It involves faith. Faith involves believing in things that can't be seen or fully comprehended by the human brain alone and scientists may have a hard time with that. Be aware that God is in charge and each day pray for guidance to give care for the best possible outcome of all concerned.

A medical doctor suggested the following:

Be open to the possibility. And be ready to act if given the opportunity. If I "talk" to God and tell him what I want, I am also expecting an answer, so each word heard after the request, or incident or coincidence is then evaluated as a possible answer to my question or desire. I am using my "intuition" for what feels right or wrong. To me, this is divine inspiration.

Nurture relationship with God. Some respondents advised that helping professionals develop a relationship with God to invite and be in tune to inspiration in their work. They proposed having faith in God, loving God, communing with God, and being willing to submit to God's will. For instance, a psychologist encouraged helping professionals to "know that there is a divine power behind it all and that we are merely God's instruments - created in His image." A respondent with a $\mathrm{PhD}$ in counseling psychology stated, "Having the desire to have a relationship with God is important. If the desire for the relationship is present, God is faithful in responding to us." A medical doctor shared the following insights for helping professionals:

Being open for inspiration and a healing touch/ presence at the beginning (and end) of each day and each appointment helps. Detachment from outcome"let me do what I'm called to do with impeccability." The outcome is between them and their Higher Power. Aligning with God first. Myself second. I'm responsible for technical knowledge/skill. I'm responsible to be a compassionate human being (but compassion for myself and my life as well-no false martyrdom or trying to earn "brownie points"). An attitude of reverence toward creation and higher power allows more of a relationship. Relating to people as "diagnoses" or the world as dead objects to be manipulated reduces a living connection that promotes inspiration and intuition.

Live a virtuous life. Participants also recommended that helping professionals live virtuous lives to increase receptivity to God's inspiration. They encouraged others to engage in religious practices such as meditation, worship and ritual, and religious readings. They also suggested that helping professional practice selfcare. For instance, a respondent with a master's degree in transpersonal psychology suggested,

Cultivate awareness of the Spirit Within. Work to heal any negative emotional issues and arrogance/bias that would get in the way of hearing and accessing the wisdom and creativity already there in full inside of us. Sit in silence a little while every day. Learn to feel emotions (as repressed emotions get in the way of the voice).

In addition, some participants believe that helping professionals are more likely to experience inspiration when they work hard at their professions, and as one medical doctor advised, "Be humble and open-minded." Others assumed that those who pursue their work with altruistic motives are more likely to experience inspiration in their work. A medical doctor offered the following advice for helping professionals:

\begin{abstract}
Orient one's efforts toward the well-being of others. It is possible to open up inspiration within oneself for purposes of self-discovery, but I think there has to be a conscious agenda of wanting to serve others to connect up one's inner transformation with the needs around one. a) It is necessary to systematically transform oneself through sustained spiritual practice, whether it be selfless work, learning to love unconditionally, seeking to know who one truly is, or striving to see the whole universe as a manifestation of the divine. We cannot arrive at inspiration with our discursive minds alone. We have to go to deeper levels of who we are, and that can be attained only through sustained and systematic effort. All religious traditions contain disciplines to that end, though they might not express them in quite this language.
\end{abstract}

Be present in relationship with clients. Some helping professionals in our study stated that God's inspiration is experienced in the encounter with the patient or client, and that it is important to demonstrate empathy, love, and presence in their work with clients and patients. A medical doctor suggested that helping professionals "stay in the moment with their patients and help them to do the same" to be receptive to inspiration. A respondent with a $\mathrm{PhD}$ in coun- 
seling psychology suggested that helping professionals do the following:

\begin{abstract}
Begin each session with the intention and attitude to seek the highest good of your client and be a channel, "instrument" of God's presence. Cultivate an attitude of humility and authentic presence in therapy. As therapists, we are often changed by the encounter as much as the client. When we relate deeply to another, God may be present. View therapy as a "social calling"; in its best moments the modern psychotherapist and priest or shaman is charged for "Care of Souls," or in Kent's words, "Soul Making."
\end{abstract}

\section{Discussion}

Our findings extend previous research by providing evidence that helping professionals from a diversity of spiritual traditions and professional specialties believe that God inspires and assists them in their professional work. This finding is consistent with several small-scale qualitative studies reported in the literature, but it represents the first large survey that documents this phenomenon. The ways respondents in our study described their experiences with inspiration were consistent in a number of ways that helping professionals in other studies have reported their experiences with inspiration (Chamberlain et al., 1996; West, 2000; White, 2002).

A number of our respondents described a type of spiritual connection or communion, reminiscent of the I-Thou relationship described by Buber (1996), which enhances therapists' empathy for their clients and helps both the client and the helping professional to grow. Helping professionals in our study and other studies have described this experience in several ways, including (a) feeling part of something bigger than themselves or their client; (b) feeling that grace is present; (c) feeling that God is present; (d) feeling the presence of healing energies or spiritual beings; (e) feeling that something special and sacred has happened between the therapist, client, and God; and (f) feeling inspired to go beyond their natural abilities (Chamberlain et al., 1996; West, 2000; White, 2002).

Consistent with previous studies (Chamberlain et al., 1996; West, 2000; White, 2002), many of the respondents in our study reported receiving inspiration that helped them more clearly assess and understand their clients' problems and implement effective interven- tions. Our findings support the idea that spiritual guidance can enhance helping professionals' ability to effectively implement standard secular interventions, as well as commonly used spiritual interventions such as discussing the client's religious beliefs, encouraging clients to seek support from religious leaders, encouraging clients to pray, and recommending spiritual bibliotherapy. At other times, inspiration may lead helping professionals to say or do something that was not planned or typically used, such as inviting a client to engage in religious visualization, praying at the beginning of a session, playing a religious song, asking a client an unusual question, sharing an unusual insight or perception about a client, encouraging a client to engage in service to others, and encouraging a client to seek forgiveness from God (Chamberlain et al., 1996).

Another important finding of our study was that many respondents indicated that they believe there are things helping professionals can do to help them prepare to receive inspiration in their work. Some of these suggestions are consistent with previous studies. For example, one prominent suggestion that the respondents had was that helping professionals remain open to alternative ways of gaining insights, particularly insights from God. This suggestion is consistent with West's (2000) recommendation that helping professionals create a spiritual space for psychotherapy. West suggested several things that can help psychotherapists do this, including (a) accepting that treatment can be a spiritual space, (b) tolerating silence and not relying on techniques so that the spiritual space can unfold, (c) "listening" in a deep and holistic manner to spiritual impressions, (d) speaking authentically by appropriately sharing feelings of the "heart," and (e) accepting the spiritual experiences that occur.

Griffith and Griffith (2002) also discussed a number of attitudes and skills that may help therapists succeed at including the spiritual in their therapeutic conversations: (a) foster within themselves curiosity, wonder, and openness to the being of the other; (b) seek to attenuate their cynicism and certainty; (c) promote a climate of openness and respect by democratizing the structure of therapy; (d) communicate respect for the personhood of their clients; (e) sustain embodied states (pay attention to feelings and bodily sensations) that permit spiritual 
or religious experiences to be recognized, understood, and expressed; and (f) carefully listen to what clients spontaneously speak about when they feel safe and respected.

Many of the respondents to our survey encouraged helping professionals to pray for God's inspiration in their work. This suggestion is consistent with the views of others who have encouraged psychotherapists to enter into meditative, reflective, or prayerful moments before, during, or after sessions, in order to prepare themselves spiritually for inspirational insights (e.g., Richards \& Bergin, 2005; West, 2000).

It is also of interest to note that many of the theistic helping professionals in our study encouraged their colleagues to be willing to look beyond the traditional constraints of naturalistic science and practice and allow for divine influences to guide the helping process (O'Grady \& Richards, 2009; Richards \& Bergin, 2005). In addition, they expressed their view that it is not only important to earn the degree and do the hard clinical work, but that it is also important to live a life that welcomes God's influence in the healing art.

\section{Limitations}

There were some limitations to the study. The findings of this study cannot be generalized with confidence beyond this sample of participants, but consistent with other studies conducted within the qualitative research tradition, it was not the goal of the study to generalize the findings to a larger population. Neither was this study designed to document the percentage of helping professionals throughout the country who believe in inspiration or who experience inspiration. The focus of this study was to learn whether a sample of helping professionals who believe in God report experiencing inspiration in their professional practices. The survey nature of the study was also a limitation in the sense that personal interviews with respondents may have yielded more in-depth responses.

\section{Conclusion}

We recognize that not all intuitive connections with clients indicate spiritual influences in the relationship and not all hunches are transcendent spiritual insights; some may occur when one's clinical experience and impressions come together in a nonrational, holistic manner. Although such experiences are difficult to explain rationally, spiritual explanations need not be invoked to account for them.

Nevertheless, devout believers in all the theistic world religious traditions embrace the belief that God can spiritually guide and enlighten human beings. Our study and other studies indicate that some helping professionals believe that transcendent spiritual guidance and enlightenment are possible and that these experiences sometimes facilitate powerful healing moments in therapy (e.g., Chamberlain et al., 1996; Richards \& Potts, 1995; West, 2000). Our findings raise the possibility that spiritual resources for change exist beyond the ordinary clinical procedures that are used.

When helping professionals receive spiritual impressions, they should not, of course, tell clients that they have received a revelation from God on the client's behalf. Helping professionals should act on their spiritual impressions cautiously and nondogmatically, remaining open to the possibility that they could be wrong (Richards \& Bergin, 2005).

Future research studies might include personal interviews of theistic helping professionals who report having experienced inspiration in their work to gain a greater depth of knowledge about inspiration in professional practice. It would also be interesting to learn through quantitative methods the prevalence of helping professionals who believe in inspiration or experience inspiration in their work by randomly sampling nationally from various helping professional organizations. Future studies might also explore whether various demographic variables are predictive of helping professionals' experiences with inspiration. We think it would also be of interest to explore how therapists' experiences with inspiration and intuition are understood from alternative worldview perspectives, including Eastern spiritual traditions, transpersonal psychology, and humanistic perspectives.

\section{References}

Barbour, I. G. (1990). Religion in an age of science: The Gifford Lectures 1989-1991 (Vol. 1). San Francisco: Harper \& Row. 
Bergin, A. E. (1980). Psychotherapy and religious values. Journal of Consulting and Clinical Psychology, 48, 75-105.

Buber, M. (1996). I and thou (W. Kaufmann, trans.). New York: Simon \& Schuster. (Original work published 1923)

Burrt, E. A. (2003). The metaphysical foundations of modern science. Minola, NY: Dover.

Capra, F. (1983). The Tao of physics: An exploration of the parallels between modern physics and Eastern mysticism (2nd ed.). Boulder, CO: Shambhala.

Chamberlain, R. B., Richards, P. S., \& Scharman, J. S. (1996). Using spiritual perspectives and interventions in psychotherapy: A qualitative study of experienced AMCAP therapists. Journal of the Association of Mormon Counselors and Psychotherapists, 22, 29-74.

Csikszentmihalyi, M. (1996). Creativity: Flow and the psychology of discovery and invention. New York: Harper Perennial.

Davies, P. (1992). The mind of God: The scientific basis for a rational world. New York: Simon \& Schuster.

Denzin, N. K., \& Lincoln, Y. S. (Eds.). (1994). Handbook of qualitative research. Thousand Oaks, CA: Sage.

Erlandson, D. A., Harris, E. L., Skipper, B. L., \& Allen, S. D. (1993). Doing naturalistic inquiry: A guide to methods. Thousand Oaks, CA: Sage.

Griffin, D. R. (2000). Religion and scientific naturalism: Overcoming the conflicts. Albany, NY: SUNY Press.

Griffith, J. L., \& Griffith, M. E. (2002). Encountering the sacred in psychotherapy: How to talk with people about their spiritual lives. New York: Guilford Press.

Karier, C. J. (1986). Scientists of the mind: Intellectual founders of modern psychology. Chicago: University of Illinois Press.

Koenig, H. G., McCullough, M. E., \& Larson, D. B. (2001). Handbook of religion and health. New York: Oxford University Press.

Leahey, T. H. (1991). A history of modern psychology. Englewood Cliffs, NJ: Prentice Hall.

Mason, S. F. (1962). A history of the sciences. New York: Macmillan.

O'Grady, K. A., \& Richards, P. S. (2009). Case study showing inclusion of spirituality in the therapeutic process. In J. D. Aten \& M. M. Leach (Eds.), Spirituality and the therapeutic process: A com- prehensive resource from intake to termination (pp. 241-265). Washington, DC: American Psychological Association.

Peacocke, A. (2001). Paths from science towards God: The end of all our exploring. Oxford, England: Oneworld.

Plante, T. G., \& Sherman, A. C. (Eds.). (2001). Faith and health: Psychological perspectives. New York: Guilford Press.

Polkinghorne, J. (1998). Belief in God in an age of science. New Haven, CT: Yale University Press.

Richards, P. S., \& Bergin, A. E. (2005). A spiritual strategy for counseling and psychotherapy (2nd ed.). Washington DC: American Psychological Association.

Richards, P. S., \& Potts, R. W. (1995). Using spiritual interventions in psychotherapy: Practices, successes, failures, and ethical concerns of Mormon psychotherapists. Professional Psychology: Research and Practice, 26, 163-170.

Shafranske, E. P. (2000). Religious involvement and professional practices of psychiatrists and other mental health professionals. Psychiatric Annals, 30, 525-532.

Simonton, D. K. (2004). Creativity in science: Chance, logic, genius, and Zeitgeist. New York: Cambridge University Press.

Slife, B. D., \& Gantt, E. E. (1999). Methodological pluralism: A framework for psychotherapy research. Journal of Clinical Psychology, 55, $1453-$ 1465.

Sperry, L., \& Shafranske, E. P. (Eds.). (2005). Spiritually oriented psychotherapy. Washington, DC: American Psychological Association.

West, W. (2000). Psychotherapy and spirituality: Crossing the line between therapy and religion. Thousand Oaks, CA: Sage.

White, F. E. (2002). The lived-experience of psychospiritual integration: A qualitative study with licensed psychotherapists who actively integrate spirituality into their practice of psychotherapy (Doctoral dissertation, Institute for Transpersonal Psychology, 2002). Dissertation Abstracts International: Section B: The Sciences and Engineering, 63, 2613.

Received July 15, 2009

Revision received December 8, 2009 Accepted December 8, 2009 